\title{
WELVAART
}

\section{FUNGSI KELUARGA DALAM PELAYANAN SOSIAL LANJUT USIA DI DESA LIABALANO KECAMATAN KONTUNAGA KABUPATEN MUNA}

Bodrus, Muhammad Arsyad, Bakri Yusuf

Fakultas Ilmu Sosial dan Ilmu Pilitik Universitas Halu Oleo

Email: Labodrus123@gmail.com, muhammadarsyad@gmail.com,

\section{Bakriyusuf0811@gmail.com}

\begin{abstract}
ABSTRAK
Di desa Liabalano Keluarga lansia mendukung kehidupan lansia. Namun tidak semua lansia tinggal bersama keluarganya. Meskipun lansia tersebut tidak tinggal bersama keluarganya, tetapi keluarga lansia dapat memperhatikan orang tuanya dengan memberikan kebutuhan serta kasih sayang kepada lansia tersebut. Penelitian ini bertujuan untuk mendeskripsikan bentuk dukungan keluarga dalam upaya meningkatkan pelayanan sosial Di Desa Liabalano Kecamatan Kontunaga Kabupaten Muna.penelitian ini menggunakan metode penelitian kualitatif. Penentuan informan dalam penelitian ini dengan carapurposive sampling. Data yang dikumpulkan dalam penelitian ini dianalisis saecara deskriptif kualitatif yaitu semua sumber data yang diperoleh dilapangang dimana data disajikan dalam bentuk kejelasan dan urayan.Teknik pengumpulan data dalam penelitian ini menggunakan tekinik wawancara, observasi dan dokumentasi.Teknik analisis data dalam penelitian ini menggunakan teknik reduksi data, penyajian data dan verifikasi. Hasil temuan yang peneliti dapatkan bahwa keluarga lansia dapat memberikian fungsi keluarga berupa, fungsi biologis, fungsi psikologi, fungsi sosial, dan fungsi ekonomi yang berpengaru dalam pelayanan sosial lanjut usiaDi Desa Liabalano Kecamatan Kontunaga Kabupaten Muna.
\end{abstract}

Kata Kunci: Fungsi Keluarga, Lansia, Pelayanan Sosial, Lanjut Usia

\section{PENDAHULUAN}

Lansia merupakan salah satu kelompok atau populasi berisiko (population at risk) yang makin meningkat jumlahnya.Allender,Rector,dan warner (2014) Mengatakn bahwa populasi beresiko (population at risk) adalah kumpulan orangorang yang masalah kesehatan nya memiliki kemungkinan akan berkembang lebih buruk kerena adanya faktor-faktor resiko yang mempengaruhi.lansiaidentik dengan berbagai penurunan status kesehatan terutama status kesehatan fisik.

Menurut Horld Health Organization (WHO) pada tahun 2013. Proporsi populasi penduduk berusia lebih dari 60 tahun adalah 11,7\% dari total populasi dunia dan akan terus meningkat sejalan dengan peningkatan usia harapan hidup. 


\section{WELVAART}

Jumlah lansia tahun 2009 telah mecapai 737 juta jiwa dan sekitar dua pertiga dari jumlah lansia tersebut tinggal di negara-negara berkembang seperti Indonesia. Diproyeksikan pada tahun 2020 populasi lansia meningkat 7,2\%, hampir sepadan denfan proporsi lansia di negara-negara maju saat ini (Tamher, 2009)

Terkait dengan meningkatnya jumlah penduduk lansia, maka permasalah sosial yang mengiringi lanjut usia adalah lanjut usia terlantar.hal ini disebabkan karena adanya perubahan struktur di dalam keluarga, keberadaan lansia di dalam lingkungan keluarga dianggap sebagai sebuah beban. Keluarga mengalami kesulitan untuk melakukan pelayanan dalam rangka memenuhi kebutuhan lansia dengan kondisi anak-anak begitu sibuk dengan masalahnya sendiri sehinggalangsung kurang memperdulikan lansia serta jalinan komunikasi antara orang tua dan anak semakin berkurang .Secara psikologi hal ini mengakibatkan para lansia merasa kesepian, merasa tidak berguna, merasa disia-siakan dan bahkan bisa menjadi terlantar.

Lansia merupakan tahap akhir dari proses penuaan. Proses menjadi tua akan dialami oleh setiap orang. Masa tua merupakan masa hidup manusia yang terakhir, dimana pada masa ini seseorang akan mengalami kemunduran fisik, mental dan sosial secara bertahap sehingga tidak dapat melakukan tugasnya sehari-hari (tahap penuruna). Penuaan merupakan perubahan kumulatif pada makhluk hidup, termasuk tubuh, jaringan dan sel, yang mengalami penurunan kapasitas fungsional.Pada manusia, penuaan dihubungkan dengan perubahan degeneratif pada kulit, tulang, jantung, pembuluh darah, paru-paru, saraf dan jaringan tubh lainnya. Dengan kemampuan degeneratif yang terbatas maka lebih rentan terkena berbagai penyakit, sindroma dan kesakitan dibandingkan dengan orang dewas lain (Kholifah, 2016).

Fungsi keluarga merupakan unsur terpenting dalam membantu lansia dalam menghadapi masalah dan menjadi salah satu cara agar lansia dapat menjaga hidup tetap sehat dan bahagia. Selain itu dengan adanya fungsi keluarga bagi lansia membuat mereka menjadi lebih bahagia.Dukungan dari orang-orang terdekat khususnya keluarga dapat membuat lansia menjadi memiliki rasa aman, 


\section{WELVAART}

berani mengambil keputusan, mengungkapakn idenya tanpa rasa takut karena melalui keluarga, berbagai masalah khususnya kesehatan dapat diatasi. Dengan adanya fungsi keluarga yang mempunyai ikatan emosional setidaknya akan memberikan kekuatan pada lansia dalam menjalani kehidupan hari tua yang lebih baik. Lansia dalam keluarga biasanya di titip ke panti jompo, tetapi tidak semua keluarga dari lansia tersebut menitip orang tua mereka, sehingga lansia yang bersangkutan tetap tinggal sama keluarganya.

\section{METODE}

Penelitian ini dilaksanakan di Desa Liabalano, Kecamatan Kontunaga, Kabupaten Muna, dengan pertimbangan bahwa di Desa Liabalano, banyak lansia tinggal bersama dengan keluarganya dan membutuhkan pelayanan sosial lanjut usia. Jenis penelitian yang dilakukan oleh peneliti adalah deskriptif kualitatif. Penelitian deskriptif kualitatif yaitu penelitian yang bermaksud untuk memahami fenomena dengan mendeskripsikan mengenai fungsi keluarga dalam pelayanan sosil lanjut usia. Dengan menggunakan jenis peneltian ini memudahkan dalam mendeskripsikan beberapa fakta-fakta dan hasil yang terjadi dilapangan penelitian (Satori 2010). Penentuan informan dilakukan peneliti menggunakan teknik purposive sampling yaitu pengambilan sumber data dengan pertimbangan tertentu yaitu informan dianggap paling tahu tentang informasi yang peneliti harapkan sehingga akan memudahkan peneliti menjelajahi objek atau situasi sosial tertentu. Adapun informan dari penelitian ini adalah keluarga yang memiliki lansia dan lansia masih tanggung jawab keluarganya.

Teknik Pengumpulan Data, Teknik observasi yaitu peneliti digunakan untuk memperoleh data tentang kondisi fisik daerah penelitian dan keadaan lansia di Desa Liabalano,Kecamatan Kontunaga, Kabupaten Muna. selain itu juga untuk mengamati lansung fungsi keluarga dalam pelayanan sosial lanjut usia di Desa Liabalano, Kecamatan Kontunaga, Kabupaten Muna.

Teknik wawancara yaitu merupakan metode yang digunakan untuk mengumpulkan data atau keterangan lisan dari seseorang yang disebut responden melalui suatu percakapan yang sistematis dan terorganisir. Wawancara ini 


\section{WELVAART}

digunakan untuk menggali sebanyak mungkin data yang terkait dengan fungsi keluarga dalam pelayanan sosial lanjut usia di Desa Liabalano, Kecamatan Kontunaga, Kabupaten Muna.

Teknik Analisa Data adalah penelitian ini dianalisis secara deskriptif yaitu semua sumber data yang diperoleh dilapangan dimana data disajikan dalam bentuk penjelasan, uraian dan pengambaran kondisi atau keadaan yang sesungguhnya tentang dengan fungsi keluarga dalam pelayanan sosial lanjut usia di Desa Liabalano, Kecamatan Kontunaga, Kabupaten Muna. Penelitian deskriptif bermaksud membuat penyadaran secara sistematis,factual, dan akuran mengenai fakta-fakta dan sifat-sifat populasitertentu. Deskriptif adalah menggambarkan atau melukiskan sesuatu hal, yaitu berupa gambar-gambar atau foto-foto dan hasil wawancara yang didapat dari data lapangan atau peneliti menjelaskan hasil penelitian dengan gambar-gambar dan dapat pula berarti menjelaskannya dengan kata-kata karena keduanya saling melengkapi (sulistiowati,2015)

\section{HASIL DAN PEMBAHASAN}

\section{Fungsi Keluarga Dalam Pelayanan Social Lanjut Usia Di Desa Liabalano Kecamatan Kontunaga Kabupaten Muna}

WHO dalam (Ratnasari 2011) membagi fungsi keluarga menjadi lima bagian yaitu fungsi biologis, fungsi psikologi, fungsi social, fungsi ekonomi, fungi pendindikan. Dimana tujuan dari adanya fungsi keluarga ini dapat memberikan kesejahteraan kepada lansia.

Adapun beberapa fungsi keluarga yang diberi kepada ketujuh lansia tersebut yaitu:

\section{a. Fungsi biologis}

Fungsi biologis yaitu untuk meneruskan keturunan, memelihara dan merawat anggota keluarga serta memenuhi kebutuhan gizi keluarga .

Sejalan dengan hal tersebut dimensi ini penulis gunakan sebagai instrument penelitian untk meninjau perihal fungsi biologis yang merupakan perilaku masyarakat dalam pelayanan social terhadapmasyarakat yang lanjut usia. 


\section{WELVAART}

Untuk mendalami aspek tersebut, peneliti melakukan observasi dan wawancara dengan beberapa informan yang telah ditetapkan dalam penelitian ini, untuk memberikan informasi/keterangan sesuai yang dibutuhkan.Hasil penelusuran penelitian terungkap sesuai fakta dan temuan dilapangan melalui deskripasi wawancara berikut.

Dari beberapa paparan informan diatas dapat terlihat bahwa adanya fungsi biologis yang diberikan kepada lansia di Desa Liabhalano.Dalam hal ini seorang anak selalu memberikan perhatian kepada kedua Orang tuanya dengan kondisi dan situasi yang dialami kedua orang tuanya. Sehingga fungsi biologis yang Nampak dalam paparan diatas adalah mengenai kesehatan, dan makan yang mengandung gizi dan tidak banyak melakukan aktivitas dalam pekerjaan untuk lanjut usia.

\section{b. Fungsi Psikologi}

Fungsi psikologi yaitu memberikan kasih sayang dan rasa aman, memberikan perhatian diantara anggota keluarga, membina pendewasaan, kepribadian anggota keluarga, serta memberikan identitas keluarga.

Dari beberapa paparan informan diatas dapat terlihat bahwa adanya fungsi psikologis yang diberikan kepada lansia di Desa Liabhalano.Dalam hal ini seorang anak selalu memberikan bentuk kassih sayang kepada kedua orang tuanya dengan kondisi dan situasi yang dialami kedua orang tuanya.Sehingga fungsi psikologis yang nampak dalam paparan diatas adalah selalu menemani orang tuannya dan memberikan rasa aman terhadapnya agar tidaak merasa kesepian di masa lanjut usianya.

\section{c. Fungsi sosial}

Fungsi sosial yaitu fungsi dalam pembinaan sosialisasi pada anak merupakan nilai-nilai keluarga, dan membina norma-norma tingkahlaku sesuai dengan tingkat perkembangan anak.

Dari beberapa paparan informan diatas dapat terlihat bahwa adanya fungsi sosial yang diberikan kepada lansia di Desa Liabhalano.sangat berbeda-beda untuk tiap keluarganya, hal ini disesuaikan dengan 


\section{WELVAART}

kondisiorang tuanya masing-masing.sebagian besaranak mengingatkan untuk selalu beribadah di masa tuanya dan bersosilisasi dengan baik.

\section{d. Fungsi ekonomi}

Fungsi ekonomi merupakan fungsi dalam mencari sumber-sumber penghasiln penghantar dalam penggunaan penghasilan keluarga dalam rangka memenuhi kebutuhan keluarga di masa mendatang.

Dari beberapa paparan informan diatas dapat terlihat bahwa adanya fungsi ekonomi yang diberikan kepada lansia di Desa Liabhalano, sebagian besar menandalkan pemberian dari anak-anaknya karena usia mereka rentan dalam penyakit, sehingga untuk keperluan kedepannya itu sepenuhnya dipenui oleh anak-anaknya.

\section{Faktot-Faktor Yang Mempengaruhi Keluarga Dalam Pelayanan} Lansia

Menurut Prasetyono dalam permana (2013) faktor yang mempengaruhi keluarga dalam peyanan lansia adalah faktor internal dan faktor eksternal.kedua faktor tersebut antara lain:

a. Faktor internal merupakan faktor yang muncul dari diri individu tersebut:

1. Faktor emosi

Emosi adalah manifestasi perasaan atau efek keluar dan disertai banyak komponen fisiologik, dan biasanya berlangsung tidak lama.Emosi berkaitan dengan psikologis seseorang dalam hal ini terkait dengam dua jenis fungsi keluarga yaitu dukungan emosional dan penilaian.

2. Pendindikan dan tingkat pengetahuan

Keluarga memiliki peran dan tanggung jawab dalam memberikan pendidikan dan tingkat pengetahuan berkaitan dengan seberapa besar pengetahuan tentang suatu penyakit. 


\section{WELVAART}

\section{b. Faktor eksternal adalah faktor luar selain dari diri individu}

1. Latar belakang budaya meliputi ras, suku, adat isti adat persepsi atau cara pandang terhadap sesuatu.

2. Struktur keluarga

Struktur keluarga merujuk pada bagaiman keluarga diorganisasikan, cara unit-unit tersebut ditata dan bagaiman komponen keluarga berinteraksi satu sama lain. Dimensi struktural keluarga meliputi struktur peran, struktur kekuasaan, pola dan proses komunikasi.

\section{KESIMPULAN}

Berdasarakan pembahasan dalam penelitian ini yang telah dilaksanakan, maka dapat disimpulkan fungsi keluarga yang diberikan keluarga kepada lansia cukup baik. Adapun fungsi keluarga yang diberikan kepada lansia yaitu:

a. Fungsi biologis yang diberikan kepada lansia di Desa Liabhalano. Dalam hal ini seorang anak selalu memberikan perhatian kepada kedua orang tuanya dengan kondisi dan situasi yang dialami kedua orang tuanya. Sehingga fungsi biologis yang Nampak dalam paparan diatas adalah mengenai kesehatan, dan makan yang mengandung gizi dan tidak banyak melakukan aktivitas dalam pekerjaan untuk lanjut usia.

b. Fungsi psikologi, anak dari nenek Wa Abe selalu menanyakan keadaan atau kondisi dari nenek Wa Abe serta selalu menawarkan ibunya untuk diemani tetangga selama dia masi disekolah dengan begitu ibunya selalu merasa diperhatikan . Dan kake La Paresa selalu diberikan perhatian dan kepedulian terhadap ksembuhan ayahnya dengan tidak membiarkan ayahnya ketergantungan dengan obat yang dapat memicu kerusakan ginjalnya.

c. fungsi sosial yang diberikan kepada lansia di Desa Liabhalano.sangat berbeda-beda untuk tiap keluarganya, hal ini disesuaikan dengan kondisiorang tuanya masing-masing. sebagian besaranak 


\section{WELVAART}

mengingatkan untuk selalu beribadah di masa tuanya dan bersosilisasi dengan baik.

d. Fungsi ekonomi yang diberikan kepada lansia di Desa Liabhalano, sebagian besar menandalkan pemberian dari anak-anaknya karena usia mereka rentan dalam penyakit, sehingga untuk keperluan kedepannya itu sepenuhnya dipenui oleh anak-anaknya.

\section{DAFTAR PUSTAKA}

Ratnasari, 2011.Pengaruh Pendidikan Kesehatan Activitas Daili Living (ADL) Lansia Terhadap Pengetahuan Dan Sikap Keluarga ( Di Wilayah Kecamatan Wonogiri) Program Pasca Sarjana Universitas Sebelas Maret.

Satori, Djam'an. 2010. Contohnya ini, dapus famillies 2010, Metodologi Penelitian Sosial.Bandung : Penerbit Alfabeta

Sulistiowati, Rela. 2015. Upaya Peningkatan Kesejahteraan Sosial Lansia Melalu Pos Pelayanan Sosial Lansia (PPS LU) DI Desa Srimartani, Kecamatan Piyungan, Kabupaten Bantul.Yogyakarta : Jurnal Pendindikan Luar Sekolah 